\title{
Preoperative optimisation in major cancer surgery: Emerging trends
}

\author{
Hilmy Ismail, MD, FRCA, FANZCA', Bernhard Riedel, MD MBA FRCA², Alexander \\ Heriot, MA, MD, MBA, FRACS, FRCS(Gen), FRCSEd ${ }^{3}$ \\ 1 Consultant Anaesthetist, Department of Anaesthetics, Peter MacCallum Cancer Centre, Melbourne, Victoria, Australia. \\ 2 Director, Department of Anaesthetics, Peter MacCallum Cancer Centre, Melbourne, Victoria, Australia. \\ 3 Assoc. Professor, Executive Director Cancer Surgery, Peter MacCullum Cancer Center, Melbourne, Victoria, Australia.
}

\begin{abstract}
Key Words: CPET, Cardio Pulmonary Exercise
Testing; PAC. Pre Operative Anaesthesia Clinics;

Preoperative Optimisation; Cancer Surgery.
\end{abstract}

\section{Introduction}

Optimising the medical and physiological status of patients presenting for major cancer surgery is an important objective and an evolving field of perioperative medicine. The demands for day of surgery admission and enhanced recovery after surgery (ERAS) requires implementation of programmes that are initiated in the preoperative period and followed through in the intraoperative and postoperative periods. These patients may also undergo neoadjuvant chemoradiation treatment (nCRT) prior to surgery. Optimising such patients for major surgery can pose added challenges.

This paper will attempt to review some of the emerging trends in this field including the role of Preoperative Anaesthesia Clinics (PAC) in the physical and nutritional optimisation of these patients and the impact of Enhanced Recovery After Surgery programmes (ERAS) on the provision of perioperative care.

\section{Multi-modal, evidence based approaches to} preoperative risk assessment and optimisation.

Preoperative risk assessment serves multiple purposes including individual risk prediction, the identification of the need for preoperative optimisation and postoperative critical care, and the subsequent sharing of this information for decision making between clinician and patient to develop a "package of care" for both the patient and the health care facility.

Objective evaluation of a patient's risk of post

Correspondence: Hilmy Ismail, Consultant Anaesthetist, Department of Anaesthetics, Peter MacCallum Cancer Centre, Melbourne, Victoria, Australia.

Email: hilmy.ismail2009@gmail.com

The Sri Lanka Journal of Surgery 2011; 29(2):58-69. operative morbidity and mortality can help identify high risk patients and in some cases result in a decision not to proceed with major surgery.

Preoperative Anaesthesia Clinics (PAC) are different to the preoperative assessment performed by a patient's anaesthetist immediately prior to surgery. The PAC consultations are performed typically weeks prior to scheduled surgery and allow for better documentation, risk assessment and optimisation strategies for patient co-morbidities.

Data from North American centres have shown significant benefits in reduction of patient anxiety,(1) hospital initiated cancellation of cases on the day of surgery, $[2,3]$ reduced length of hospital stay and significant hospital savings [3-5] with the implementation of PACs.

In 2005 an independent UK based group of perioperative physicians including anaesthetists, intensivists and surgeons (ISOG) produced a comprehensive report titled "Modernising Care For Patients Undergoing Major Surgery” (6) and proposed the following action items:

$<$ To implement new standards of care that incorporate improved preoperative assessment, preparation and triage, intraoperative care, and improved use of postoperative resources.

$<$ To establish preoperative assessment at a much earlier stage in the patient pathway, before surgery planning occurs, in order that decisions can be made about fitness for various procedures.

$\cdot<$ To break out from the 'silo' budgeting approach that currently inhibits clinical teams from spending relatively small amounts of money on technology that will save greater amounts of 
money in other areas.

$<$ To prioritise the rational use of critical care resources, making patients undergoing major surgery a priority group.

$<$ To analyse data about the current situation and evaluate the differences seen.

\section{Physiologic Capacity: Preoperative Risk Stratification and Management - the use of new technologies.}

There is a lack of consensus as to the credibility of traditional preoperative diagnostic pulmonary or cardiac function tests as risk predictors in patients undergoing major abdominal surgery, especially for tests performed at rest (static tests). Dynamic testing to assess functional capacity is increasingly recognized as an important adjunct in modern surgical care. Cardiopulmonary exercise testing (CPET) is a dynamic test and provides the gold standard for evaluating an individual's functional/physiologic capacity (fitness level) [7]. CPET-derived respiratory gas exchange analysis provides a uniquely individual and objective phenotypic assessment of the metabolic response to the stress of exercise, evaluating coupling by the cardiovascular system, of pulmonary respiration to end-organ cellular (mitochondrial) respiration [8].

\section{Impaired Functional Capacity.}

Physical conditioning (fitness) correlates with physiological capacity, and is associated with longevity $[9,10]$. Whether a patient is deconditioned due to behavioural choice, organ disease, or associated therapy e.g. chemoradiation therapy, such a reduction in physiologic capacity is increasingly recognized to represent inability to physiologically meet the metabolic demands of perioperative stress resulting in increased risk for postoperative morbidity and mortality [11-16].

A number of CPET-derived variables allow objective grading of physiologic dysfunction [8] Of these, anaerobic threshold (AT) and peak oxygen uptake (peak $\mathrm{VO}_{2}$ ) have been studied as markers of physiologic capacity that provide risk prediction for adverse postoperative outcome and used to guide perioperative decision-making.

Older et al reported that an AT value of less than 11 $\mathrm{mL} / \mathrm{min} / \mathrm{kg}$ represented the critical level of physiologic capacity that identified elderly patients having major abdominal surgery at high risk of postoperative cardiac mortality. Patients with an AT less than $11 \mathrm{~mL} / \mathrm{min} / \mathrm{kg}$ had an $18 \%$ in-hospital cardiac mortality rate, whereas patients with a higher AT value had a $0.8 \%$ mortality rate [11]. These authors also recommended stratification of levels of postoperative care based on the AT and Ve/VO2. [12,13] (Table 2).

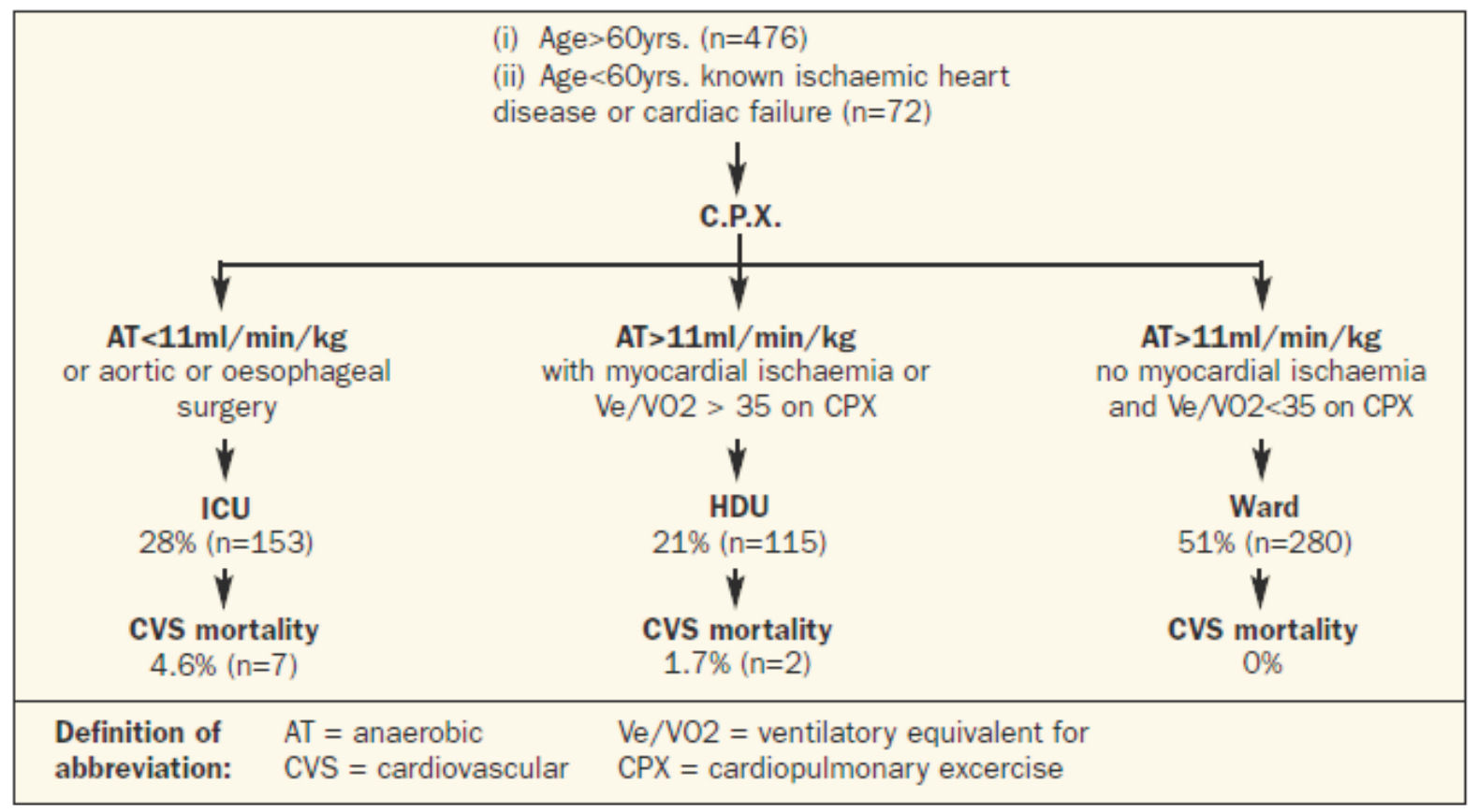

Figure 1. Results of triage based on CPET testing [13] 
More recent studies have confirmed the value of CPET based objective assessment of physiologic capacity in improving risk prediction for adverse surgical outcome. Snowden et al reported that an AT less or equal to $10 \mathrm{~mL} / \mathrm{kg} / \mathrm{min}$ was associated with increased postoperative complications and length of hospital stay(14); Smith et al confirmed that peak $\mathrm{VO}_{2}$ and possibly AT were valid predictors of postoperative morbidity and mortality in thoraco-abdominal surgery [15]; Hightower et al reported improved risk prediction $(\mathrm{AUC}=0.85$, sensitivity $=88 \%$, and specificity $=79 \%$ ) for adverse surgical outcome after major abdominal cancer surgery [16]. Nagamatsu et al supported the usefulness of peak oxygen uptake (less than $800 \mathrm{~mL} / \mathrm{min} / \mathrm{m}^{2}$ ) as a predictor of postoperative morbidity in patients undergoing oesophagectomy [17] and Forshaw et al reported that patients suffering cardiorespiratory complications after oesophagectomy had significantly lower peak $\mathrm{Vo}_{2}$ [18] Similar studies have been done on patients having liver transplantation,(19) major elective intraabdominal surgery [20], and surgery for aortic aneurysms [21].

These data strongly suggest that: [1] Patients can complete a maximal effort, symptom limited CPET test prior to undergoing major surgery; [2] preoperative parameters of physiologic capacity (AT and peak $\mathrm{VO}_{2}$ ) are significantly associated with postoperative complications [3] CPET derived parameters can be utilised to develop care pathways leading to better outcomes.

Conceivably, as a result of the previous ISOG report and emerging evidence, CPET testing has seen a renewed interest in the UK with approximately 1 in 3 NHS trusts and anaesthetic departments now having access to this test [22].

\section{Declining Physiologic Capacity after neoadjuvant CRT.}

In patients with gastro-intestinal cancer having preoperative neoadjuvant chemoradiation a finite window of time exists wherein surgery should be performed, allowing physiologic recovery from neoadjuvant CRT but avoiding the unfavourable radiation-induced tissue changes if surgery is performed too early or too late after neoadjuvant CRT. The timing of the surgery is largely empirical and not based on objective assessment of recovery of physical function from neoadjuvant CRT. Accurate determination of the time to return to optimal baseline fitness would potentially have a major impact on the timing of surgery, postoperative outcome, and timing of adjuvant CRT. The ability to utilize CPET to objectively evaluate recovery and guide interventional strategies (e.g. nutrition and exercise prescription) to expedite recovery to ensure optimal physiologic function after neoadjuvant CRT would ensure that definitive cancer resection occurs within the most optimal time frame.

Preliminary data demonstrate that physiologic capacity may deteriorate by as much as $20-30 \%$ following neoadjuvant CRT $[23,24]$. Given the increased risk of adverse postoperative outcome with poor physiologic capacity (e.g. AT less than 11 $\mathrm{mL} / \mathrm{kg} / \mathrm{min}$ [12]) such a decline in physiologic capacity after neoadjuvant CRT may suggest that previously "fit" patients now fall below this threshold and thus potentially are at increased risk for adverse postoperative outcomes. At the present time, the ability to credibly identify adequate recovery from deconditioning that follows neoadjuvant CRT is lacking, with further study needed to determine if patients would benefit from postponement of surgery until they have recovered to above this threshold of physiologic capacity. Whether such a waiting period would adversely impact long-term cancer outcome and whether acute preoperative optimisation (e.g. nutritional or exercise intervention) will accelerate recovery to above this threshold and thereby reduce postoperative risk is unknown

\section{Exercise Capacity Intervention The Evidence}

There is potential for pre-surgical exercise training to improve a patient's cardio-respiratory fitness and to potentially reduce postoperative morbidity and mortality and improve postsurgical recovery. Mechanisms whereby exercise training may prove as an effective therapy include reduction in endothelial dysfunction and inflammatory statusfactors central to postoperative morbidity [25]. In a review and metaanalysis of 12 studies, preoperative exercise therapy consisting of inspiratory muscle training or exercise training led to a shorter hospital stay and complication rates in patients undergoing cardiac or abdominal surgery but not joint replacement surgery [26]. While exercise regimens may be logistically difficult to administer, studies have shown that in patients who attended greater than $80 \%$ of prescribed training 
sessions, preoperative peak $\mathrm{VO}_{2}$ was increased by $3.3 \mathrm{~mL} / \mathrm{kg} / \mathrm{min}$ [27].

In a landmark prospective randomized trial Arthur et al demonstrated that 8 weeks of multimodal, CPET based exercise intervention prior to cardiac surgery resulted in reduced length of hospital and intensive care stay post surgery[28].

A pilot study to determine the feasibility and preliminary effectiveness of an individually designed preoperative therapeutic exercise program in cancer patients awaiting elective abdominal/thoracic surgery for 5 weeks showed $84 \%$ attendance of sessions with significant increase in cardio respiratory fitness and muscle strength despite the relatively short period of training [29].

Larger studies are required to see if preoperative "prehabilitation" with exercise therapy is logistically feasible and cost-effective as a therapy to reduce postoperative morbidity and mortality.

\section{Impaired Nutritional Status.}

The prevalence of malnutrition in patients with cancer varies according to tumour type, location, and treatment [30] but is generally reported as high as 20 $80 \%$, [31] with patients with tumours of the upper gastrointestinal (UGI) tract at particularly high risk of malnutrition on presentation [32]. This has a negative impact on immunocompetence, neo-adjuvant treatment tolerance, wound healing, hospital length of stay, and increased costs [33-35]. Nutritional status can be further significantly compromised by the side effects of multi-modal treatment regimens such as neoadjuvant CRT.

Malnutrition screening is a simple process that is used to identify patients at nutritional risk who require a more thorough and detailed nutrition assessment. Current dietetic best practice guidelines recommend that all oncology patients in the acute care setting be screened for malnutrition [30,35,36]. The Malnutrition Screening Tool (MST) [37] is an easily implemented method of identification patients who need a more thorough nutritional assessment. The scored Patient-Generated Subjective Global Assessment (scored PG-SGA) [38, 39] or Subjective Global Assessment (SGA) [38, 39] are both validated in the oncology patient population, and recommended by current guidelines [35]. These tools categorise the degree of malnutrition as either well- nourished (SGA A); moderate or suspected malnutrition (SGA B); or severely malnourished (SGAC).

\section{Nutrition Support Options - The Evidence.}

The European Society of Parenteral and Enteral Nutrition (ESPEN) guidelines on enteral nutrition in surgery recommend nutritional support in patients with severe nutritional risk for 10-14 days prior to major surgery [40] .These guidelines define severe nutritional risk to have at least one of the following: weight loss greater than 10-15\%within 6 months; Body Mass Index (BMI) less than $18.5 \mathrm{~kg} \cdot \mathrm{m}^{-2}$; and SGA score C or serum albumin below $30 \mathrm{~g} / \mathrm{L}$ (with no evidence of hepatic or liver dysfunction). Similarly, the United Kingdom's National Institute for Clinical Excellence (NICE) guidance document on nutrition support recommends preoperative enteral tube feeding in patients scheduled for major abdominal procedures who are identified as malnourished and unable to meet nutritional requirements orally [41]. The early identification and management of patients demonstrating impaired nutritional status is of particular importance in patients undergoing major upper gastrointestinal cancer surgery. Many of these patients will require supplementary nutrition due to dysphagia. The appropriate method of nutrition support is best determined on an individualised basis by a specialist dietitian in consultation with the patient, family and treating team. These options usually include oral nutrition support and tube feeding when appropriate. Total Parenteral Nutrition (TPN) is indicated in rare cases only.

Patients undergoing neoadjuvant CRT prior to surgery raise particular issues relating to the side effects of treatment and frequently require supplemental tube feeding. In these patients the option of prophylactic gastrostomy, a naso-enteric feeding tube or surgical jejunostomy allows the provision of supplemental enteral nutrition to be titrated according to the level of oral intake achieved as the patient progresses throughout treatment. Compared to relying on oral intake alone, this improves the patient's nutritional status both pre- and postoperatively $[42,43]$.

While nutritional intervention may improve functional capacity, including recovery from neoadjuvant CRT [44], further studies are required to delineate whether an improvement in nutritional 
status, through intervention, will improve surgical outcome.

\section{Immunonutrition}

The rapidly evolving field of pharmaconutrition indicates that the future of surgical and ICU nutrition will involve administration of specific pharmaconutrients [45]. These nutrients are classified into three families for clarity: Immune-modulating (arginine), anti-inflammatory (Omega-3 Fatty Acids ( $n$-3FA), glutamine) and cell protective (glutamine, antioxidants).

Research investigating the benefits of oral and enteral nutritional formulae enriched with these nutrients indicate that they play a role in modulating the immune system, with improved clinical outcomes such as reduced rate of infection, length of hospital stay, [46,47] and wound complications [45,48]. Guidelines from professional nutrition societies around the world identify certain patients who may benefit from specific pharmaconutrients and recommend arginine, glutamine and $n$-3FA in most critically ill patients. However, extreme caution has been advised in the use of arginine in patients with sepsis [45]. The use of preoperative enteral nutrition, preferably with immune modulating substrates, in patients undergoing major abdominal cancer surgery including oesophagectomy and gastrectomy is likewise supported by the ESPEN Guidelines on enteral nutrition $[40,49]$.

In a subsequent report by the same group (ISOG) multiple hospitals in the UK have reported improved results in lengths of hospital care, access to critical care, and cost reductions from implementation of a range of perioperative optimisation strategies including the use of CPET based triage to critical care [50].

\section{Enhanced Recovery Protocols.}

ERAS programmes are increasingly being incorporated into care pathways for patients presenting for major cancer surgery. ERAS is a multimodal perioperative care pathway that is designed to attenuate the patient's stress response during the patient's surgical journey. This concept of multi-modal care was pioneered in the late 1990s by Professor Henrik Kehlet [51] and has been implemented with success in a number of European centres particularly in the context of colorectal surgery. The establishment of The ERAS Study Group in 2001 and subsequent publications [52,53] have radically changed the perioperative management of these patients resulting in protocolised, evidence based management pathways.

A summary of the recommendations made in these publications [53-55] are reflected in Table 1.

Table 1. Adapted with permission from Varadhan et al [55].

A recent metanalysis of six randomised controlled trials have shown that implementation of ERAS programmes resulted in shorter durations of hospital stay and reduced complications with no difference to re-admission rates or mortality [54]. These results are postulated to flow from the three goals of ERAS programmes: reduction of physiological stress, support of organ function and reduction in postoperative morbidity.

It is however, noteworthy that the individual elements of ERAS have been independently subjected to scientific evaluation and should therefore be readily transferable in combination or in isolation to noncolorectal surgery settings. Although the evidence is limited, there are multiple reports of ERAS pathways resulting in reduction in lengths of hospital stay and complications in patients undergoing thoracic,(56) urology, [57] oesophageal, [58] pancreatic, [59] liver, $[60,61]$ and vascular $[62,63]$ surgery.

The implementation of these programs require considerable time and effort. It has also been argued that a patient's length of hospital stay is significantly affected by organisational factors such as bed availability and discharge policies rather than the use of ERAS protocols alone [64]. Also, the economic benefit of shorter hospital stay may not be realised if early discharge results in higher than desired readmission rates. This may be a significant factor in the developing world where community support services may not be adequate.

\section{Conclusion}

Preoperative anaesthesia clinics provide a unique opportunity for the co-ordinated implementation of evidence based, multimodal strategies aimed at optimising patients prior to major cancer surgery. Although the emerging evidence for nutritional and physical "prehabilitation" of patients is looking promising, there is a need for audit and research of this 
Table 1. Summary of measures for preoperative optimisation in major cancer surgery

\begin{tabular}{|c|c|c|}
\hline Preoperative phase & Rationale & Recommendation \\
\hline $\begin{array}{l}\text { Preadmission } \\
\text { information and } \\
\text { counselling }\end{array}$ & $\begin{array}{l}\text { Preadmission counselling ensures a clear } \\
\text { understanding of the intended } \\
\text { perioperative care to be received with } \\
\text { emphasis on attaining specific preset } \\
\text { targets that help alleviate the stress } \\
\text { responses to surgery. }\end{array}$ & $\begin{array}{l}\text { Provision of oral and written patient } \\
\text { information regarding hospitalization, } \\
\text { pain relief, and achieving postoperative } \\
\text { targets such as early nutrition, } \\
\text { mobilization, and discharge. }\end{array}$ \\
\hline No bowel preparation & $\begin{array}{l}\text { Bowel preparation leads to dehydration } \\
\text { and changes in fluid and electrolyte } \\
\text { balance with possible increased risk for } \\
\text { complications, such as prolonged } \\
\text { postoperative ileus, and anastomotic } \\
\text { leakage. }\end{array}$ & $\begin{array}{l}\text { Patients undergoing elective colonic } \\
\text { resection above the peritoneal reflection } \\
\text { should not receive routine oral bowel } \\
\text { preparation. Bowel preparation may be } \\
\text { considered in low rectal resection where } \\
\text { a diverting stoma is planned. }\end{array}$ \\
\hline $\begin{array}{l}\text { Preoperative } \\
\text { nutritional support }\end{array}$ & $\begin{array}{l}\text { Approximately } 27-45 \% \text { of hospitalized } \\
\text { patients are malnourished with increased } \\
\text { risk for tissue wasting, impaired immune } \\
\text { function, impaired healing, and organ } \\
\text { dysfunction. Preoperative carbohydrate } \\
\text { loading reduces the incidence of } \\
\text { complications and facilitates accelerated } \\
\text { recovery through early return of gut } \\
\text { function and shorter hospital stay } \\
\text { leading to an improved perioperative } \\
\text { well being. }\end{array}$ & $\begin{array}{l}\text { Patients should receive carbohydrate } \\
\text { enriched drinks preoperatively. } \\
\text { Patients should be screened for } \\
\text { malnutrition and those at risk should be } \\
\text { given preoperative nutritional support, } \\
\text { orally if possible. }\end{array}$ \\
\hline Preoperative fasting & $\begin{array}{l}\text { Preoperative fasting and surgery } \\
\text { predisposes to metabolic stress and } \\
\text { insulin resistance. Overnight fasting } \\
\text { does not reduce the risk for aspiration. } \\
\text { Intake of clear fluids until } 2 \text { hours before } \\
\text { anaesthesia is safe. }\end{array}$ & $\begin{array}{l}\text { The consensus guidelines from a } \\
\text { Cochrane review and guidelines from } \\
\text { anaesthetic societies recommend clear } \\
\text { fluids until } 2 \text { hours before induction of } \\
\text { anaesthesia and a 6-hour fast for solid } \\
\text { food. }\end{array}$ \\
\hline $\begin{array}{lr}\text { No long-acting } \\
\text { sedatives } \\
\text { premedication }\end{array}$ & $\begin{array}{l}\text { Long-acting sedatives, hypnotics, and } \\
\text { opioids (pre-emptive analgesia) were } \\
\text { thought to reduce anxiety and stress } \\
\text { related to surgery, but these effects are } \\
\text { far outweighed by the risk for prolonged } \\
\text { recovery caused by inability to drink or } \\
\text { mobilize postoperatively. No effect on } \\
\text { postoperative pain relief is achieved by } \\
\text { starting analgesic treatment before the } \\
\text { operation. Short-acting anxiolytics have } \\
\text { not shown prolonged recovery or length } \\
\text { of stay. }\end{array}$ & $\begin{array}{l}\text { Medications causing long-term sedation } \\
\text { should be avoided. Short-acting } \\
\text { medications given to facilitate insertion } \\
\text { of epidural catheter are acceptable. }\end{array}$ \\
\hline
\end{tabular}




\begin{tabular}{|c|c|c|}
\hline $\begin{array}{l}\text { Antimicrobial } \\
\text { prophylaxis }\end{array}$ & $\begin{array}{l}\text { Prophylactic antibiotics minimize } \\
\text { infectious complications in colorectal } \\
\text { surgery. }\end{array}$ & $\begin{array}{l}\text { A single dose, } 1 \text { hour before skin } \\
\text { incision and further doses for } \\
\text { procedures lasting more than } 3 \text { hours. }\end{array}$ \\
\hline $\begin{array}{l}\text { Venous } \\
\text { Thromboembolism } \\
\text { (VTE) prophylaxis }\end{array}$ & $\begin{array}{l}\text { Increased risk for thromboembolic } \\
\text { complications in certain high-risk patien ts } \\
\text { undergoing major abdominal surgery is } \\
\text { associated with prolonged ho spitalization } \\
\text { and recovery. }\end{array}$ & $\begin{array}{l}\text { Subcutaneous low-dose unfractionated } \\
\text { heparin or subcutaneous low molecular- } \\
\text { weight heparin. A wareness of need for } \\
\text { extended postoperative VTE } \\
\text { prophylaxis in high risk patients. }\end{array}$ \\
\hline Intraoperative phase & Rationale & Recommendation \\
\hline $\begin{array}{l}\text { Standard anaesthetic } \\
\text { protocol utilising mid- } \\
\text { thoracic epidural. }\end{array}$ & $\begin{array}{l}\text { Rational use of short-acting agents to } \\
\text { facilitate rapid recovery. Preoperative } \\
\text { commencement of mid-thoracic epidural } \\
\text { blocks stress hormone release and } \\
\text { attenuates postoperative insulin resistance. } \\
\text { Helps achieve analgesia with opioid } \\
\text { sparing effect, sympathetic blockade and } \\
\text { reduce gut paralysis. }\end{array}$ & $\begin{array}{l}\text { Avoid long-acting opioids. Mid- } \\
\text { thoracic epidural commenced } \\
\text { preoperatively, containing local } \\
\text { anaesthetic in combination with a low- } \\
\text { dose opioid. Consider short-acting } \\
\text { inhalational anaesthesia as an } \\
\text { alternative to total intravenous } \\
\text { anaesthesia. }\end{array}$ \\
\hline $\begin{array}{l}\text { Laparoscopic/ } \\
\text { Minimally invasive } \\
\text { surgery }\end{array}$ & $\begin{array}{l}\text { Decreased inflammatory response, insulin } \\
\text { resistance, improved pulmonary function, } \\
\text { early return of bowel function, } \\
\text { mobilization, less pain, reduced incidence } \\
\text { of complications, readmissions, and length } \\
\text { of stay. }\end{array}$ & $\begin{array}{l}\text { Laparoscopic-assisted colorectal } \\
\text { surgery is recommended in dedicated } \\
\text { specialist centres, with outcomes } \\
\text { comparable to open surgery. }\end{array}$ \\
\hline $\begin{array}{l}\text { Maintenance of } \\
\text { Normothermia }\end{array}$ & $\begin{array}{l}\text { Reduced wound infections, cardiac } \\
\text { complications, bleeding, and transfusion } \\
\text { requirements. }\end{array}$ & $\begin{array}{l}\text { Routine use of upper-body, forced-air } \\
\text { heating cover; prevention of } \\
\text { hypothermia by warm intravenous } \\
\text { fluids. }\end{array}$ \\
\hline $\begin{array}{l}\text { Optimise fluid } \\
\text { management }\end{array}$ & $\begin{array}{l}\text { Sodium and fluid overload delays return of } \\
\text { gastrointestinal function, prolongs hospital } \\
\text { stay, increases side-effects and } \\
\text { complications. }\end{array}$ & $\begin{array}{l}\text { Fluid restriction, avoiding hypovolemia, } \\
\text { sodium, and fluid overload. Goal- } \\
\text { directed fluid therapy in high-risk cases. }\end{array}$ \\
\hline Selective use of drains & $\begin{array}{l}\text { Routine use of drains does not reduce the } \\
\text { incidence or severity of anastomotic leak. }\end{array}$ & $\begin{array}{l}\text { No drains after routine colonic } \\
\text { resections above peritoneal reflections. } \\
\text { Short-term (less than } 24 \text { hours) drainage } \\
\text { after low anterior resections. }\end{array}$ \\
\hline Urinary drainage & $\begin{array}{l}\text { Increased risk for urinary tract infections } \\
\text { following prolonged use. }\end{array}$ & $\begin{array}{l}\text { Early removal of catheters following } \\
\text { colonic surgery. }\end{array}$ \\
\hline
\end{tabular}




\begin{tabular}{|c|c|c|}
\hline Postoperative Phase & Rationale & Recommendation \\
\hline $\begin{array}{l}\text { No routine use of } \\
\text { nasogastric tube }\end{array}$ & $\begin{array}{l}\text { Facilitates earlier return of bowel function. } \\
\text { Not asso ciated with increased risk for } \\
\text { complications or length of stay. }\end{array}$ & $\begin{array}{l}\text { Nasogastric tubes should not be used } \\
\text { routinely in the posto perative period. } \\
\text { Used in selected cases of postoperative } \\
\text { ileus. Early fluid and diet re-in troduction. }\end{array}$ \\
\hline $\begin{array}{l}\text { Aggressive tre atment } \\
\text { of post op erative } \\
\text { nausea and } \\
\text { vomiting(PONV) }\end{array}$ & $\begin{array}{l}\text { Facilitates early oral feed ing. Symptoms } \\
\text { related to postoperative ileus and opioids } \\
\text { can be more stressful than postoperative } \\
\text { pain. (Female gender, non-smoking status, } \\
\text { history of motion sickness or PONV, and } \\
\text { postoperative opioids confer high risk of } \\
\text { PONV.) }\end{array}$ & $\begin{array}{l}\text { Individuals at risk should receive, } \\
\text { prophylactically o ne anti-emetic agent } \\
\text { per risk factor to a maximum of } 3 \text { agents } \\
\text { at induction or at the end of surgery. }\end{array}$ \\
\hline $\begin{array}{l}\text { Preventing } \\
\text { postoperative ileus }\end{array}$ & $\begin{array}{l}\text { Surgical stress, opioids, bowel hand ling, } \\
\text { and fluid overload predispose to ileus and } \\
\text { impaired gut function, leading to delayed } \\
\text { discharge. Oral magnesium oxide promotes } \\
\text { postoperative bowel function. }\end{array}$ & $\begin{array}{l}\text { Mid-tho racic epidural analgesia, } \\
\text { avoidance of fluid overload, and } \\
\text { laparoscopic approach if locally } \\
\text { validated is recommended. A low-dose } \\
\text { postoperative laxative, such as } \\
\text { magnesium oxide, may also be } \\
\text { considered. }\end{array}$ \\
\hline $\begin{array}{l}\text { Optimise post } \\
\text { operative analgesia. }\end{array}$ & $\begin{array}{l}\text { Mid-Thoracic Epidural Analgesia results in } \\
\text { better pain relief and earlier return of bowel } \\
\text { function compared with Patient Controlled } \\
\text { Analgesia. Ineffective pain control, } \\
\text { analgesia with oral or intravenous opiates, } \\
\text { lack of mobility, and loss of appetite } \\
\text { contributes to the delayed G I recovery. }\end{array}$ & $\begin{array}{l}\text { Continuous mid-thoracic epidural with } \\
\text { low-dose local anaesthetic and opioid } \\
\text { combinations for approximately } 48 \text { ho urs } \\
\text { following elective colonic surgery and } \\
\text { approximately } 72-96 \text { hours after pelvic } \\
\text { surgery. Acetaminophen (paracetamol) } \\
\text { for baseline analgesia ( } 4 \mathrm{~g} / \mathrm{d}) \text {, and } \\
\text { NSAIDS started following removal of } \\
\text { epidural (multimodal analgesia). Urinary } \\
\text { catheter does not have to stay for full } \\
\text { duration of epidural and should be } \\
\text { removed at earliest. }\end{array}$ \\
\hline $\begin{array}{l}\text { Post operative } \\
\text { nutrition. }\end{array}$ & & $\begin{array}{l}\text { Encourage oral diet at will after surgery. } \\
\text { Oral supplements (approx. } 200 \mathrm{~mL} \text {, } \\
\text { energy dense, 2-3 times daily) from day } \\
\text { of surgery un til normal intake. Continue } \\
\text { oral supplements for several weeks for } \\
\text { nutritionally depleted patients. }\end{array}$ \\
\hline Early mobilisation & & $\begin{array}{l}\text { The care plan should include } \\
\text { mobilisation out of bed for } 2 \text { hours on the } \\
\text { day of surgery and every } 6 \text { hours } \\
\text { thereafter. }\end{array}$ \\
\hline Audit & & $\begin{array}{l}\text { Systematic audits should be performed to } \\
\text { benchmark performance with comparable } \\
\text { units. }\end{array}$ \\
\hline
\end{tabular}


evolving area of perioperative medicine.

There is a significant body of evidence that CPET testing can provide a safe, cost effective method of risk stratification of these patients. Whether this will allow determination of pre-optimisation and post operative care pathways leading to improved patient outcomes will become apparent as the results of more research are published.on the best possible clinical and costeffective outcomes for the patient and the health service concerned [6].

\section{References}

1. Klopfenstein CE, Forster A, Van Gessel E. Anesthetic assessment in an outpatient consultation clinic reduces preoperative anxiety. Canadian journal of anaesthesia $=$ Journal canadien d'anesthesie. 2000;47(6):511-5.

2. Ferschl MB, Tung A, Sweitzer B, Huo D, Glick DB. Preoperative clinic visits reduce operating room cancellations and delays. Anesthesiology. 2005;103(4):855-9.

3. van Klei WA, Moons KG, Rutten CL, Schuurhuis A, Knape JT, Kalkman CJ, et al. The effect of outpatient preoperative evaluation of hospital inpatients on cancellation of surgery and length of hospital stay. Anesthesia and analgesia. 2002;94(3):644-9; table of contents.

4. Pollard JB, Garnerin P, Dalman RL. Use of outpatient preoperative evaluation to decrease length of stay for vascular surgery. Anesthesia and analgesia. 1997;85(6):1307- 11.

5. Wijeysundera DN, Austin PC, Beattie WS, Hux JE, Laupacis A. A population-based study of anesthesia consultation before major noncardiac surgery. Archives of internal medicine. 2009;169(6):595-602.

6. ISOG. Modernising Care For Patients Undergoing M a jor Surgery. Http://www.reducinglengthofstay.org.uk/do c/isog report.pdf 2005; Available from: http://www.reducinglengthofstay.org.uk/do c/isog report.pdf.

7. Palange P, Ward SA, Carlsen KH, Casaburi R , Gallagher CG, Gosselink $R$, et al. Recommendations on the use of exercise
Testing in clinical practice. The European respiratory journal : official journal of the European Society for Clinical Respiratory Physiology. 2007;29(1):185-209.

8. Wasserman K, Hansen JE, Sue DY, Stringer WW, Whipp BJ. Principles of Exercise Testing and Interpretation. 4 ed: Lippincott Williams \& Wilkins.; 2005.

9. Myers J, Prakash M, Froelicher V, Do D, Partington S, Atwood JE. Exercise capacity and mortality among men referred for exercise testing. The New England journal of medicine. 2002;346(11):793-801.

10. Gulati M, Pandey DK, Arnsdorf MF, Lauderdale DS, Thisted RA, Wicklund RH, et al. Exercise capacity and the risk of death i n women: the St James Women Take Heart Project. Circulation. 2003;108(13):1554-9.

11. Older P, Smith R, Courtney P, Hone R. Preoperative evaluation of cardiac failure and ischemia in elderly patients by cardiopulmonary exercise testing. Chest. 1993;104(3):701-4.

12. Older P, Hall A. Clinical review: how to identify high-risk surgical patients. Crit Care. 2004;8(5):369-72.

13. Older P, Hall A, Hader R. Cardiopulmonary exercise testing as a screening test for perioperative management of major surgery in the elderly. Chest. 1999;116(2):355-62.

14. Snowden CP, Prentis JM, Anderson HL, Roberts DR, Randles D, Renton $\mathrm{M}$, et al. Submaximal cardiopulmonary exercise testing predicts complications and hospital length of stay in patients undergoing major elective surgery. Annals of surgery. 2010;251(3):535-41.

15. Smith TB, Stonell C, Purkayastha S, Paraskevas P. Cardiopulmonary exercise testing as a risk assessment method in non cardio-pulmonary surgery: a systematic review. Anaesthesia. 2009;64(8):883-93.

16. Hightower CE, Riedel BJ, Feig BW, Morris GS, Ensor JE, Jr., Woodruff VD, et al. A pilot study evaluating predictors of postoperative outcomes after major abdominal surgery: Physiological capacity compared with the ASA physical status classification system. British journal of anaesthesia.2010;104(4):465-71. 
17. Nagamatsu Y, Shima I, Yamana H, Fujita H, Shirouzu K, Ishitake T. Preoperative evaluation of cardiopulmonary reserve with the use of expired gas analysis during exercise testing in patients with squamous cell carcinoma of the thoracic esophagus. The Journal of thoracic and cardiovascular surgery. $2001 ; 121(6): 1064-8$.

18. Forshaw MJ, Strauss DC, Davies AR, Wilson D, Lams B, Pearce A, et al. Is cardiopulmonary exercise testing a useful test before esophagectomy? The Annals of thoracic surgery. 2008; 85(1):294-9.

19. Epstein SK, Freeman RB, Khayat A, Unterborn JN, Pratt DS, Kaplan MM. Aerobic capacity is associated with 100-day outcome after hepatic transplantation. Liver transplantation : official publication of the American Association for the Study of Liver Diseases and the International Liver Transplantation Society. 2004;10(3):41824.

20. Wilson RJ, Davies S, Yates D, Redman J, Stone M. Impaired functional capacity is associated with all-cause mortality after major elective intra-abdominal surgery. British journal of anaesthesia. 2010;105(3):297-303.

21. Carlisle J, Swart M. Mid-term survival after abdominal aortic aneurysm surgery predicted by cardiopulmonary exercise testing. The British journal of surgery. 2007;94(8):966-9. Epub 2007/04/19.

22. Huddart s PP, Young E, et al. National Cardiopulmonary Exercise Testing for Preoperative Assesment Survey 2011. 4th National Peri0Operative CPET Meeting; 6th July 2011; London 2011.

23. West MJ, S. Barben, C, Grocott, M. The effect of Neoadjuvant Chemoradiotherapy on Fitness in Patients undergoing Rectal Cancer Surgery- a Piliot Study. 4th National Per-Operative CPET Meeting; 6th July, 2011; London 2011.

24. Jack SW, Raw M, Sturgess D, Grocott R. The effect of Neoadjuvant Chemotherapy on Fitness in Patients undergoing tumour resection for Upper Gastrointestinal Cancer. 4th National Peroperative CPET Meeting,; 6th July, 2011.; London 2011.

25. Ribeiro F, Alves AJ, Duarte JA, Oliveira J. Is exercise training an effective therapy targeting endothelial dysfunction and vascular wall inflammation? International journal of cardiology. 2010;141(3):214-21.

26. Valkenet K, van de Port IG, Dronkers JJ, de Vries WR, Lindeman E, Backx FJ. The effects of preoperative exercise therapy on postoperative outcome: a systematic review. Clinical rehabilitation. 2011;25(2):99-111.

27. Jones LW, Peddle CJ, Eves ND, Haykowsky MJ, Courneya KS, Mackey JR, et al. Effects of presurgical exercise training on cardiorespiratory fitness among patients undergoing thoracic surgery for malignant lung lesions. Cancer. 2007;110(3):590-8.

28. Arthur HM, Daniels C, McKelvie R, Hirsh J, Rush B. Effect of a preoperative intervention on preoperative and postoperative outcomes in low-risk patients awaiting elective coronary artery bypass graft surgery. A randomized, controlled trial. Annals of internal medicine. 2000;133(4):253-62.

29. Timmerman H, de Groot JF, Hulzebos HJ, de Knikker R, Kerkkamp HE, van Meeteren NL. Feasibility and preliminary effectiveness of preoperative therapeutic exercise in patients with cancer: a pragmatic study. Physiotherapy theory and practice. 2011;27(2):117-24.

30. Bauer JD AS, Davidson WL, Hill JM, Brown T, Isenring EA, Reeves M. Evidence based practice guidelines for the nutritional management of cancer cachexia. Nutrition \& Dietetics. 2006;63(S3-2).

31. Kubrak C, Jensen L. Critical evaluation of nutrition screening tools recommended for oncology patients. Cancer nursing. 2007;30(5):E1-6.

32. Garth AK, Newsome CM, Simmance N, Crowe TC. Nutritional status, nutrition practices and post-operative complications in patients with gastrointestinal cancer. J Hum Nutr Diet. 2010;23(4):393-401. 
33. McClave SA, Snider HL, Spain DA Preoperative issues in clinical nutrition. Chest. 1999;115(5 Suppl):64S-70S.

34. Dempsey DT, Mullen JL, Buzby GP. The link between nutritional status and clinical outcome: can nutritional intervention modify it? The American journal of clinical nutrition. 1988;47(2 Suppl):352-6.

35. Watterson C FA, Banks M, Isenring E, Miller $\mathrm{M}$, Silvester $\mathrm{C}$, et al. . Evidence based practice guidelines for the nutritional management of malnutrition in adult patients across the continuum of care. Nutrition \& Dietetics 2009;66 (Suppl 3):1-34.

36. Isenring E. Consensus-based nutritional recommendations for patients with heada nd-neck cancer. Curr Oncol. 2011;18(4):165-6.

37. Ferguson M, Capra S, Bauer J, Banks M. Development of a valid and reliable malnutrition screening tool for adult acute hospital patients. Nutrition. 1999;15(6):45864.

38. FD O. Patient generated subjective global assesment. The clinical guide to oncology nutrition. Chicago : The American Dietetic Asociation.: McCallum PD, Polisena CG.; 2011.p. 11-23.

39. Detsky AS, McLaughlin JR, Baker JP, Johnston N, Whittaker S, Mendelson RA, et al. What is subjective global assessment of nutritional status? JPEN J Parenter Enteral Nutr. 1987;11(1):8-13. Epub 1987/01/01.

40. Weimann A, Braga M, Harsanyi L, Laviano A, Ljungqvist $\mathrm{O}$, Soeters $\mathrm{P}$, et al. ESPEN Guidelines on Enteral Nutrition: Surgery including organ transplantation. Clin Nutr. 2006;25(2):224-44. Epub 2006/05/16.

41. Nutrition Support for Adults Oral Nutrition Support, Enteral Tube Feeding and Parenteral Nutrition. 2006; Available from: http://www.nice.org.uk/nicemedia/pdf/ cg032fullguideline.pdf.

42. Jenkinson AD, Lim J, Agrawal N, Menzies D. Laparoscopic feeding jejunostomy in esophagogastric cancer. Surg Endosc. 2007;21(2):299-302.

43. Martin L, Lagergren J, Jia C, Lindblad M, Rouvelas I, Viklund P. The influence of
Needle catheter jejunostomy on weight development after oesophageal cancer surgery in a population-based study. Eur J Surg Oncol. 2007;33(6):713-7.

44. Isenring EA, Capra S, Bauer JD. Nutrition intervention is beneficial in oncology outpatients receiving radiotherapy to the gastrointestinal or head and neck area. $\mathrm{Br} \mathrm{J}$ Cancer. 2004;91(3):447-52.

45. Wischmeyer P. Nutritional pharmacology in surgery and critical care: 'you must unlearn what you have learned'. Current opinion in anaesthesiology. 2011;24(4):381-8.

46. Waitzberg DL, Saito H, Plank LD, Jamieson GG, Jagannath $\mathrm{P}$, Hwang TL, et al. Postsurgical infections are reduced with specialized nutrition support. World J Surg. 2006;30(8):1592-604.

47. Zheng Y, Li F, Qi B, Luo B, Sun H, Liu S, et al. Application of perioperative immunonutrition for gastrointestinal surgery: a meta-analysis of randomized controlled trials. Asia Pac J Clin Nutr. 2007;16 Suppl 1:253-7. Epub 2007/03/30.

48. Marik PE, Zaloga GP. Immunonutrition in high-risk surgical patients: a systematic review and analysis of the literature. JPEN J Parenter Enteral Nutr. 2010;34(4):378-86.

49. Allum WH, Griffin SM, Watson A, ColinJones D. Guidelines for the management of oesophageal and gastric cancer. Gut. 2002;50 Suppl 5:v1-23.

50. ISOG. Modernising Care For Patients Undergoing Major Surgery. [ $\mathrm{Imple} \mathrm{me} \mathrm{m}$ a $\mathrm{t}$ i o n G u ide] http://www.reducinglengthofstay.org.uk/ doc/ISOG2.pdf2007; Available from: http://www.reducinglengthofstay.org.uk/ doc/ISOG2.pdf.

51. Kehlet H. Multimodal approach to control postoperative pathophysiology and rehabilitation. B r J Anaesth. 1997;78(5):606-17. Epub 1997/05/01.

52. Fearon KC, Ljungqvist $\mathrm{O}$, Von Meyenfeldt $\mathrm{M}$, Revhaug A, Dejong $\mathrm{CH}$, Lassen $\mathrm{K}$, et al. Enhanced recovery after surgery: a consensus review of clinical care for patients undergoing colonic resection. Clin Nutr. 2005;24(3):466-77. Epub 2005/05/18 
53. Lassen K, Soop M, Nygren J, Cox PB, Hendry PO, Spies C, et al. Consensus review of optimal perioperative care in colorectal surgery: Enhanced Recovery After Surgery (ERAS) Group recommendations. Arch Surg. 2009;144(10):961-9.

54. Varadhan KK, Neal KR, Dejong $\mathrm{CH}$, Fearon $\mathrm{KC}$, Ljungqvist $\mathrm{O}$, Lobo DN. The enhanced recovery after surgery (ERAS) pathway for patients undergoing major elective open colorectal surgery: a meta-analysis of randomized controlled trials. Clin Nutr. 2010;29(4):434-40.

55. Varadhan KK, Lobo DN, Ljungqvist $\mathrm{O}$. Enhanced recovery after surgery: the future of improving surgical care. Critical care clinics. 2010;26(3):527-47.

56. McKenna RJ, Jr., Mahtabifard A, Pickens A, Kusuanco D, Fuller CB. Fast-tracking after video-assisted thoracoscopic surgery lobectomy, segmentectomy, and pneumonectomy. The Annals of thoracic surgery. 2007;84(5):1663-7; discussion 7-8.

57. Arumainayagam N, McGrath J, Jefferson $\mathrm{KP}$, Gillatt DA. Introduction of an enhanced recovery protocol for radical cystectomy. BJU international. 2008;101(6):698-701.

58. Jiang K, Cheng L, Wang JJ, Li JS, Nie J. Fast track clinical pathway implications in esophagogastrectomy. World journal of gastroenterology : WJG. 2009;15(4):496501.

59. Balzano G, Zerbi A, Braga M, Rocchetti S, Beneduce AA, Di Carlo V. Fast-track
Recovery programme after pancreaticoduodenectomy reduces delayed gastric emptying. The British journal of surgery. 2008;95(11):1387-93.

60. MacKay G, O'Dwyer PJ. Early discharge following liver resection for colorectal metastases. Scottish medical journal. 2008;53(2):22-4.

61. van Dam RM, Hendry PO, Coolsen MM, Bemelmans $\mathrm{MH}$, Lassen $\mathrm{K}$, Revhaug $\mathrm{A}$, et al. Initial experience with a multimodal enhanced recovery programme in patients undergoing liver resection. The British journal of surgery. 2008;95(8):969-75.

62. Murphy MA, Richards T, Atkinson C, Perkins J, Hands LJ. Fast track open aortic surgery: reduced post operative stay with a goal directed pathway. European journal of vascular and endovascular surgery : the official journal of the European Society for Vascular Surgery. 2007;34(3):274-8.

63. Muehling B, Schelzig H, Steffen P, Meierhenrich R, Sunder-Plassmann L, Orend KH. A prospective randomized trial comparing traditional and fast-track patient care in elective open infrarenal aneurysm repair. World journal of surgery. 2009;33(3):577-85.

64. Maessen J, Dejong CH, Hausel J, Nygren J, Lassen $\mathrm{K}$, Andersen $\mathrm{J}$, et al. A protocol is not enough to implement an enhanced recovery programme for colorectal resection. The British journal of surgery. 2007;94(2):22431. 